Premiere Educandum: Journal of Basic Education and Learning

Volume 11 (1) 75 - 86 June 2021

ISSN: 2088-5350 (Print) / ISSN: 2528-5173 (Online)

Doi: $10.25273 /$ pe.v11i1.7928

The article is published with Open Access at: http://e-journal.unipma.ac.id/index.php/PE

\title{
Implementation of the school literacy movement during the covid-19 pandemic
}

Atikah Mumpuni $\bowtie$, Muhadi Setiabudi University

Prasetyo Yuli Kurniawan, Muhadi Setiabudi University

Rizki Umi Nurbaeti, Muhadi Setiabudi University

Annisa Nurul Fadillah, Muhadi Setiabudi University

Meri Yuliyanti, Muhadi Setiabudi University

Nova Indriyani, Muhadi Setiabudi University

atikahmumpuni@umus.ac.id

\begin{abstract}
The implementation of the school literacy movement, especially in elementary schools, has many obstacles. Moreover, during the Covid-19 pandemic, the problem of implementing the school literacy movement became increasingly complex. This research is a qualitative research, which is carried out in elementary schools in Banjarharjo District. The data collection instruments consisted of interviews, questionnaire sheets, and observation sheets. The results showed 1) the pattern of literacy movements during the Covid-19 pandemic was adjusted to the level of developmental age of students and the situation and conditions and stages of the literacy movement carried out online; 2) The driving factors for the implementation of the school literacy movement during the Covid-19 pandemic include the availability of good facilities and cooperation with parents. Meanwhile, The inhibiting factors for the school literacy movement are the lack of supporting facilities and the lack of teachers to directly control the development of students' literacy. The school literacy movement during the Covid-19 pandemic should be supported by digital-based reading materials and parental understanding regarding the implementation of the school literacy movement during the Covid-19 pandemic.
\end{abstract}

Keywords: literacy movement, elementary school, covid-19

Received 30 November 2020; Accepted 04 April 2021; Published 01 June 2021

Citation: Mumpuni, A., Kurniawan, PY, Nurbaeti, RU, Fadilla, AN, Yuliyanti, M., \& Indriyani, N. (2021). Implementation of the school literacy movement during the covid-19 pandemic. Premiere Educandum: Jurnal Pendidikan dan Pembelajaran, 11(1), 75 - 86. Doi.org/10.25273/ pe.v11i1.7928

\section{(cc) BY-Ne-sA}

Copyright (C) 2021 Premiere Educandum: Journal of Basic Education and Learning

Published by PGRI Madiun University. This work is licensed under the Creative Commons Attribution-NonCommercial-

ShareAlike 4.0 International License. 


\section{INTRODUCTION}

Initially, the literacy movement existed to eradicate illiteracy by improving people's reading and writing skills. Along with the times, people need information not only by being able to read and write. However, it is also able to understand the information it receives and use it intelligently. Thus, the scope of the literacy movement becomes broader, including reading, writing, and the ability to understand and analyze information.

Literacy can have a positive impact if it is carried out sustainably. The concept of literacy develops continuously throughout the child's life(Buvaneswari \& Padakannaya, 2017). The government proclaimed literacy in the school literacy movement as a continuous effort to foster good influence in students. The school literacy movement began to be launched, along with the intensification of character education. School is considered an effective place to develop positive habits. Habituating positive attitudes and behaviors in schools is integrated into the literacy movement, namely by familiarizing students with reading and writing to foster character. Therefore, the implementation of the literacy movement, especially in elementary schools, deserves more attention.

The school literacy movement activities carried out include three stages. The three stages of the school literacy movement can be carried out through habituation, development, and learning(Faizah, 2016). The first is the habituation stage; all school members will be accustomed to reading activities. The reading material chosen should be reading material that all school members can enjoy. Interesting reading material can be chosen to read together between the teacher and students to foster reading habits both in students and teachers(Baterstock et al., 2019) .

Second, the development stage; the expected bill is to understand the information that has been received. Literacy helps to read symbols and makes it possible to formulate connected meanings to facilitate oneself to transcend deeper realities (Gellel, 2018). Thus, understanding the meaning in this stage of literacy development will support a person in developing himself. Third, the literacy learning stage; at this stage literacy, begins to be included in learning activities. Literacy learning carried out in schools is in line with the implementation of the 2013 Curriculum. In the 2013 curriculum, students will be accustomed to reading and understanding texts and summarizing and restating in their language (Suwandi, 2019). Therefore, in the 2013 Curriculum, knowledge and information are packaged in various reading texts.

The implementation of the literacy movement in elementary schools is generally constrained by human resources, availability of facilities, and cooperation with outsiders. The low awareness of the teachers, the lack of enthusiasm for the teachers with reading material, and the implementation of the literacy movement, which the teacher does not fully understand, are obstacles to the implementation of the school literacy movement in terms of human resources (Coal \& Ariani, 2018). he lack of facilities and infrastructure, such as reading rooms, reading materials, or supporting posters, also makes it difficult for schools to implement the school literacy movement (Dafit \& Ramadan, 2020). Finally, the obstacle to implementing the school literacy movement is the lack of parental participation in supporting literacy activities; this results in the reading habit stage not developing optimally (Kurniawan et al., 2019).

Similar obstacles related to the implementation of the school literacy movement happen in elementary schools in Banjarharjo District. It can be seen from the use of Student Worksheets (LKPD) or student books used as reading material at the habituation stage. Another obstacle is the lack of supporting facilities and facilities. It can be seen in several schools that do not provide a library in the corner of the class. Thus, the lack of variation in the development of activities at each stage and the lack of support for implementing the school literacy movement from various elements have resulted in the school literacy movement not running optimally. These problems are increasingly complex when the school literacy movement must still be carried out, even amid the Covid-19 pandemic. 
During the Covid-19 pandemic, students are required to study at home to break the chain of spreading the virus. It means there is a shift in the learning process, which is usually done in person, switching online. Besides providing convenient online learning, there are also obstacles such as an unsupportive environment and inadequate facilities (Herliandry et al., 2020). Online learning during the Covid-19 pandemic made students feel bored and felt less effective for primary schools to implement (Putria et al., 2020).

The number of obstacles and complaints during online learning has undoubtedly become a challenge in implementing the school literacy movement in elementary schools during the Covid-19 pandemic. Therefore, research related to implementing the school literacy movement during the Covid-19 pandemic needs to be done. Through this research, an accurate picture will be known regarding implementing the school literacy movement during the Covid-19 pandemic. In addition, this research will also reveal the obstacles in implementing the school literacy movement during the Covid-19 pandemic. Thus, this research can be used as an evaluation material and a basis for developing the school movement during the further Covid-19 pandemic.

\section{METHODS}

\section{Research Design}

This research is qualitative research that will explore, describe, and analyze the implementation of the school literacy movement during the Covid-19 pandemic. This research design refers to the model proposed by Miles \& Huberman. The model components are presented in Figure 1, as follows.

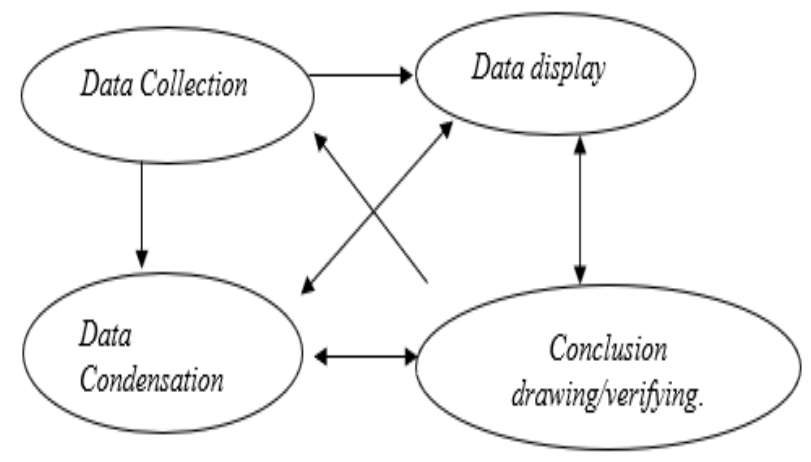

FIGURE 1. Components in data analysis (interactive model)(Higgs et al., 2019)

\section{Research subject}

This research was conducted in the odd semester of the 2020/2021 school year, namely from September to December 2020, in the Banjarharjo District elementary schools. Three elementary schools were randomly selected from three villages in Banjarharjo District. The three elementary schools are 1) SDN Cikunya 03 is located Cikuya Village; 2) SDN Cigadung 03 is located in Cigadung Village; 3) SDN Ciawi is located in Ciawi Village. The subjects of this study were divided into two, namely: 1) teachers and principals as implementers of the school literacy movement and 2) parents of students as outsiders supporting the school literacy movement.

\section{Research Instruments and Indicators}

There were three instruments used for data collection, namely: 1) the observation sheet for the means and facilities to support the school literacy movement; 2) a questionnaire sheet for the involvement of parents / guardians in the implementation of the school literacy movement; and 3) interview guidelines for the implementation of the literacy 
movement in elementary schools from the point of view of principals and teachers.

In the form of an observation sheet, the first instrument is presented in the form of a checklist table to make it easier for researchers to analyze the availability of facilities and facilities to support the school literacy movement, especially during the Covid-19 pandemic. The observation sheet presented is also equipped with a description column to make it easier for researchers to record specific things found in the field. The observation sheet refers to the indicators of means and facilities to support the implementation of the literacy movement presented in Table 1 as follows.

TABLE 1. Indicators of facilities and facilities to support the implementation of the school literacy movement during the covid-19 pandemic

\begin{tabular}{|c|c|c|}
\hline No. & $\begin{array}{l}\text { School Literacy } \\
\text { Movement Stage }\end{array}$ & Indicator of Supporting Facilities and Facilities \\
\hline \multirow{3}{*}{1.} & \multirow{3}{*}{ The habituation stage } & $\begin{array}{l}\text { a. There is regular recording related to books read to or read } \\
\text { by students }\end{array}$ \\
\hline & & b. There are posters that support literacy activities \\
\hline & & c. The presence of rich text material \\
\hline \multirow[b]{2}{*}{2.} & \multirow[b]{2}{*}{ Development Stage } & a. There is a portfolio assessment in response to reading \\
\hline & & $\begin{array}{l}\text { b. There is an observation sheet used to observe students' } \\
\text { reading activities }\end{array}$ \\
\hline \multirow{3}{*}{3.} & \multirow{3}{*}{ Learning stage } & a. There is an enrichment book \\
\hline & & b. There is a school reading area \\
\hline & & $\begin{array}{l}\text { c. There is an academic award that takes into account the } \\
\text { literacy skills of students }\end{array}$ \\
\hline
\end{tabular}

TABLE 2. Interview guidelines for the implementation of the school literacy movement during the covid-19 pandemic

\begin{tabular}{|c|c|c|}
\hline No. & Aspect & Indicator \\
\hline \multirow{2}{*}{1.} & \multirow{2}{*}{$\begin{array}{l}\text { Implementation of the } \\
\text { school literacy } \\
\text { movement during the } \\
\text { Covid-19 pandemic }\end{array}$} & $\begin{array}{l}\text { a. The activity stage of the School Literacy Movement during } \\
\text { the Covid-19 pandemic }\end{array}$ \\
\hline & & $\begin{array}{l}\text { b. The pattern of activities of the School Literacy Movement } \\
\text { during the Covid-19 pandemic }\end{array}$ \\
\hline \multirow{3}{*}{2.} & \multirow{3}{*}{$\begin{array}{l}\text { The factors driving and } \\
\text { inhibiting the } \\
\text { implementation of the } \\
\text { school literacy } \\
\text { movement during the } \\
\text { Covid-19 pandemic }\end{array}$} & $\begin{array}{l}\text { a. Supporting factors for the implementation of the School } \\
\text { Literacy Movement during the Covid-19 pandemic }\end{array}$ \\
\hline & & $\begin{array}{l}\text { b. Inhibiting factors for the implementation of the School } \\
\text { Literacy Movement during the Covid- } 19 \text { pandemic }\end{array}$ \\
\hline & & $\begin{array}{l}\text { c. Solutions made by schools to minimize obstacles to } \\
\text { implementing the School Literacy Movement during the } \\
\text { Covid-19 pandemic }\end{array}$ \\
\hline
\end{tabular}

The following instrument is a questionnaire on the involvement of parents in the implementation of the literacy movement in elementary schools. The questionnaire made in this study refers to indicators of the involvement of parents/guardians in the implementation of the school literacy movement during the Covid-19 pandemic. The indicators consist of two things, namely: 1) the existence of public involvement in the provision of suggestions and facilities to support the school literacy movement and 2) the existence of a school literacy team that collaborates with public elements. There are 20 statements in the questionnaire presented. Furthermore, the questionnaire is presented on a Likert scale with four answer choices: strongly agree, agree, disagree, and strongly disagree.

The third instrument is the interview guide for the implementation of the literacy movement in elementary schools. Interview guidelines were developed concerning the 
indicators presented in Table 2 as follows.

The questions in the interview were made using open-ended questions because of the possibility of varying the answers from teachers in each elementary school. Interviews were conducted online both through calls and messages, considering that it was still in a pandemic condition, so not all teachers were in school.

\section{Data analysis}

Qualitative research data analysis includes data reduction, data presentation, and conclusion. Reduction is made to sort the data according to the problem formulation and research questions. Data presentation is done by describing the research data obtained and linking it with relevant theories. Finally, concluding will answer the formulation of the problem and research questions from the presentation of the data.

\section{RESULTS}

Patterns and stages of implementing the school literacy movement during the covid19 pandemic

\section{Implementation Pattern}

The pattern of the school literacy movement during the Covid-19 pandemic was varied. In general, the three elementary schools used as research sites, namely SDN Cikunya 03, SDN Cigadung 03, and SDN Ciawi carry out the pattern of the school literacy movement online. It is because during the Covid-19 pandemic learning was carried out from home for the good of all.

The pattern of literacy movements during the Covid-19 pandemic was also differentiated between low-class students and high-class students. It is like the pattern of the school literacy movement during the Covid-19 pandemic, which was held at SD Negeri Ciawi. The results of the interview with KS1 stated that,

"The pattern of the school literacy movement in low classes is carried out by asking students to record their reading activities. Whereas in high class, the teacher does not ask students to record their reading activities. "

The difference in literacy movements between low and high classes is done because the lower class is still in the initial reading and writing stages. Meanwhile, the higher class students are already in the advanced reading and writing stages. Recording reading activities carried out by lower grade students aims to observe students' reading activities directly. Thus, teachers can immediately correct if there are errors in the reading process and know the development of students' reading skills.

It is different from the pattern of the school literacy movement carried out at SD Negeri Cikuya 03, which combines online and offline. The results of the interview with KS2 stated that,

"Students in lower grade literacy movements are carried out offline and online every Monday with strict health protocols. The pattern of the school literacy movement, which is carried out offline, is divided into class I, class II and class III sessions. "

The pattern of offline literacy movements carried out in lower grade classes with strict health protocols is carried out so that teachers can see first-hand the literacy process of students. In addition, parents also continue to accompany students in implementing the school literacy movement during the Covid-19 pandemic. 
The pattern of offline and online literacy movements was also carried out at SD Negeri Cigadung 01. The results of the interview with KS2 stated that,

"Offline activities are only carried out once every two weeks, to take reading material that the school has provided. "

Offline activities are carried out to minimize the limitations of reading materials that can only be accessed offline. Therefore, schools need to regulate the distribution of lending reading material to still carry out the habituation stage through the available reading materials.

\section{Implementation Stage}

The implementation stage of the school literacy movement, in general, has three stages, namely the habituation, development and learning stages. However, based on the primary school teachers' accounts, the three stages were deemed not optimal when implemented online. It is under the results of an interview with GK1, which stated that,

"In the habituation stage, reading activities 15 minutes before the learning activities have been carried out. Only the implementation is not optimal, apart from the lack of reading material that can be accessed online, there is also a lack of interaction and teacher supervision in reading activities 15 minutes before learning activities. "

In this habituation stage, the teacher's role is to provide space and time for students to read various reading materials 15 minutes before learning begins. Meanwhile, parents' supervision and assistance are mostly carried out, considering the learning process is still at home. GK2 also confirmed this in an interview which stated that,

"The success of reading habit 15 minutes before online lessons begin is greatly influenced by the role of parents. The role of parents in this activity is huge; apart from supervising, they should also be able to provide examples and motivate students. "

Thus, this habituation activity will be able to foster students' love for reading activities.

Furthermore, at the stage of developing the literacy movement during the Covid-19 pandemic, this was carried out through a portfolio assessment. The results of the interview with GK3 stated that,

"Assessment through portfolios needs to be done because the teacher in this stage of development not only knows the final results of the students' understanding of the reading material they have read. However, teachers also need to know the process of these activities to assess their overall achievement."

Portfolio assessment will allow the teacher to see the process carried out by students, even though learning is carried out from home. GK4, in the results of the interview, stated,

"One example of portfolio assessment at the development stage in literacy movement activities during the Covid-19 pandemic is recording reading activities carried out by students. "

This method is done so that the teacher can determine students' accuracy in pronouncing words, sentences, and paragraphs. In addition, it is also to find out students' understanding of punctuation marks in the reading text. Based on the interviews that have 
been conducted, the assessment of the literacy movement during the Covid-19 pandemic has not been carried out online. Teachers from the three elementary schools are still conducting direct assessments. It is because the online assessment application or platform is not yet available.

The last is the learning stage; of course, this stage is carried out online. The literacy learning stage during the Covid-19 pandemic was mostly carried out by inserting learning materials. The results of the interview with GK1 stated,

"Enrichment books or school reading areas are not widely used during learning from home because they are only available in the offline form, except for schools that are still inserting offline amid the Covid-19 pandemic. "

It is like what happened in SD Negeri Cikuya 03, which still imposes offline activities for low-grade students once a week. In addition, SD Negeri Cigadung 01 is still offline to pick up enrichment books that can be used to support the school literacy movement during the Covid-19 pandemic.

\section{Driving factors and inhibiting factors for the implementation of the school literacy movement during the Covid-19 pandemic}

The driving force and support for the school literacy movement during the Covid-19 pandemic, of course, cannot be separated from the availability of supporting facilities and facilities for GLS. Based on the observations that have been made, both SDN Cikunya 03, SDN Cigadung 03, and SDN Ciawi have similarities. The availability of supporting facilities for GLS at SDN Cikunya 03, SDN Cigadung 03, and SDN Ciawi 01, is presented in Table 3 as follows.

TABLE 3. Availability of supporting facilities and facilities for GLS in elementary schools

\begin{tabular}{|c|c|c|}
\hline No. & $\begin{array}{l}\text { Indicator of GLS Supporting Facilities } \\
\text { and Facilities }\end{array}$ & $\begin{array}{l}\text { Availability of supporting facilities and } \\
\text { facilities for GLS at SDN Cikunya 03, SDN } \\
\text { Cigadung 03, SDN Ciawi }\end{array}$ \\
\hline 1. & Regular note-taking & No regular logs \\
\hline 2. & $\begin{array}{l}\text { Poster supporting the school literacy } \\
\text { movement }\end{array}$ & Available offline \\
\hline 3. & Text rich material & $\begin{array}{l}\text { Available, in limited numbers, and can only be } \\
\text { accessed offline }\end{array}$ \\
\hline 4. & $\begin{array}{l}\text { There is a portfolio assessment to } \\
\text { respond to reading }\end{array}$ & Available offline \\
\hline 5. & $\begin{array}{l}\text { The existence of an observation sheet to } \\
\text { observe students' reading activities }\end{array}$ & Available offline \\
\hline 6. & Enrichment books are available & Available, in a limited number, and offline \\
\hline 7. & There is a reading area & There is only a library room at the school \\
\hline 8. & $\begin{array}{l}\text { There are academic awards that are } \\
\text { given taking into account literacy skills }\end{array}$ & $\begin{array}{l}\text { There are no academic awards that take } \\
\text { literacy skills into account }\end{array}$ \\
\hline
\end{tabular}

The availability of supporting facilities and facilities as presented in Table 3 shows that most of the supporting facilities and facilities at SDN Cikuya 03, SDN Cigadung 03, and SDN Ciawi 01 have been fulfilled. There are only a few things that have not been fulfilled, namely, regular recording and academic awards. In addition, the availability of facilities and facilities that are only available offline is undoubtedly an obstacle in implementing GLS during the Covid-19 pandemic.

Apart from observations, researchers also conducted in-depth interviews related to supporting and inhibiting factors for implementing GLS during the Covid-19 pandemic. 
Many things support the factors driving the implementation of the school literacy movement. The results of the interview with GK4 obtained the following results.

"Most of the students do have gadgets, and some parents are also actively providing additional reading material to students, as well as accompanying students in implementing the school literacy movement during the Covid-19 pandemic. "

The existence of devices during the Covid-19 pandemic is undoubtedly a major supporting factor. However, the existence of this device needs the availability of adequate quotas and networks.

The involvement of parents in the process of the school literacy movement is undoubtedly an added point for the sustainability of the program. However, the involvement of parents is not accompanied by an understanding of the implementation of the school literacy movement. It is reinforced by the results of the interviews presented by GK4, that:

"Parents are very enthusiastic in assisting students in implementing the school literacy movement program. However, it is not accompanied by a good understanding regarding the implementation of the school literacy movement, thus making the literacy movement implemented into a place. "

Therefore, parental involvement needs to be accompanied by an understanding of the program to run effectively and efficiently.

The factors inhibiting the implementation of the school literacy movement during the Covid-19 pandemic were generally almost same between SD Negeri Ciawi, SD Negeri Cikuya 03, and SD Negeri Cigadung 01, namely related to supporting facilities and infrastructure. The first is related to the availability of reading material used in the habituation process. The results of the interview with GK1 stated that,

"Digital reading materials such as ebooks already exist in this school, but are still stored on CDs, in limited quantities, and cannot be accessed online. "

The limitations of reading material make schools have to play ways to have the opportunity to read the available reading material. Therefore, in its use, it is carried out alternately so that all students can read it. SDN Cikuya 03 and SDN Ciawi 01 also felt the same thing regarding the limited reading material. The results of the interview with GK2 stated that,

"Limited reading material has made teachers use textbooks more often in the process of getting used to reading."

Of course, this becomes an obstacle when it is carried out in habituation activities. The books used in habituation should be interesting enrichment books and filled with character values to foster students' reading habits.

The limited reading material was circumvented by SD Negeri Ciawi, SD Negeri Cikuya 03, and SD Negeri Cigadung 01 by lending alternately to students. Not only that, facilities such as libraries can only be accessed offline, so it does not support the online literacy movement. Therefore, one of the alternatives that Cigadung 01 Elementary School has done is to lend enrichment books to students in turn.

The second inhibiting factor, namely, the availability of gadget facilities, is not matched by quotas and a stable network. It was reinforced by the results of the interview with GK3, as follows. 
"Many students have devices, but they are more often used to play games. Apart from that, the existence of devices is often not matched by adequate quotas and networks. "

The existence of devices that are not used according to their function and are not supported by the availability of adequate quotas and networks, have made students lag in implementing the school literacy movement during the Covid-19 pandemic even though the implementation of the school literacy movement during the Covid-19 Pandemic was mostly carried out at home with the help of adequate communication facilities.

The third inhibiting factor, the implementation of the literacy movement carried out at home, makes teachers less direct to control students' literacy development. GK3 stated in an interview that was conducted stating that:

"I had difficulty during the evaluation process because I could not see the students' progress directly. The collaboration in evaluating the implementation of the literacy movement together with parents makes the assessment less objective because parents tend to cover up students' weaknesses. "

Assessments that are sometimes carried out based on the results of collaboration with parents sometimes do not fully describe the development of students. Therefore, to minimize this problem, teachers usually make assessments based on the results of the portfolio assignments given to students.

Similar results were also obtained from SD Negeri Cikuya 03, that the role of parents is very large in implementing the school literacy movement. The existence of good cooperation in the implementation of these activities is the key to the successful implementation of the literacy movement during the Covid-19 pandemic. This is because during the Covid-19 pandemic more students were at home with their parents.

So far, the cooperation related to the implementation of the literacy movement during the pandemic carried out by parents has only been limited to mentoring students. Based on a questionnaire that has been distributed to parents, as many as $75 \%$ of the students' parents admitted they did not understand, 15\% of parents knew a little, and the rest understood the concept of the school literacy movement. The assistance provided by new parents is limited to the direction given by the teacher.

Furthermore, the results of a questionnaire related to the involvement of parents in the implementation of the school literacy movement during the Covid-19 pandemic, obtained several results. 1) As many as $68 \%$ of parents admit that the school is not involved in providing facilities and facilities to support the school literacy movement, $20 \%$ of them prefer to take the initiative to provide their own, and the rest say they are involved because they are active in school committee activities. 2) As many as $72 \%$ of parents do not know about the collaboration of the literacy team with public elements, $15 \%$ of parents do not know about the existence of the school literacy team, while $13 \%$ of parents are aware of the cooperation of the literacy team with public elements. The public elements that are intended include local government, regional libraries, and the community.

\section{DISCUSSION}

\section{Patterns and Stages of Implementing the School Literacy Movement During the Covid-19 Pandemic}

The literacy movement will encourage the development of good character in students. The results of previous research indicate that there is an influence between the school literacy movement on the character values of students, with a determination coefficient of 22.9\%.(Labudasari \& Rochmah, 2019). Furthermore, good literacy skills will allow students to develop themselves optimally so that something good is achieved too 
(Tryanasari et al., 2017). Therefore, the school literacy movement must be carried out in all situations, including during the Covid-19 pandemic.

The pattern of implementing the school literacy movement during the Covid-19 pandemic was generally carried out online. The online system is one way to create social distancing so that it can minimize the appearance of crowds that are considered to have the potential to spread Covid-19 (Handarini \& Wulandari, 2020). School is one of the environments that have the potential to create a crowd. Therefore, all activities at school are carried out online in the hope that teachers and students will avoid Covid-19.

Activities that were previously carried out face-to-face, then turned online, are certainly not easy things. There are many adjustments to be made and obstacles to overcome for the success of the activity. The constraints experienced by teachers in the online system are related to applications used, internet networks, devices, management of activities, assessment, and supervision (Rigianti, 2020). These obstacles were also faced by teachers in the pattern of implementing the school literacy movement during the Covid-19 pandemic.

Besides the obstacles that arise, the accuracy of implementing the school literacy movement carried out online will improve students' literacy skills. It is supported by the results of previous research which states that e-learning has been proven to improve students' digital literacy skills (Anggrasari, 2020). Online system constraints in implementing the school literacy movement certainly result in differences in treatment between low and high classes. Different treatment patterns between high and low classes in the implementation of the school literacy movement during the Covid-19 pandemic were found in terms of activity management, assessment and supervision. This difference in treatment was carried out because they were still in the initial reading and writing stages in the lower classes.

In lower grade students, most of them still have some reading problems. The research states that some of the difficulties in reading at the beginning of grade I elementary school students are the spelling time, which is quite long and have not been read completely(Pratiwi \& Ariawan, 2017). herefore, the management of activities, assessment, and supervision must also be adjusted so that teachers can know the development of their reading and writing skills.

Meanwhile, literacy activities are carried out under the stage of the school literacy movement, which is carried out face-to-face, consisting of habituation, development, and learning (Faizah, 2016). The stage of this stage is, of course, adjusted to the stage of development of students. In addition, it is also adjusted to the situation and conditions during the Covid-19 pandemic, which is mostly done online.

Every stage of implementing the online school literacy movement requires good collaboration with parents. Parents have an essential role in exemplifying literacy culture at home(Marmoah et al., 2019). During the implementation of the school literacy movement during the Covid-19 pandemic, parents also participated in guiding and supervising the implementation of the literacy movement. The implementation of literacy during the Covid-19 pandemic was mostly carried out from home; automatically, interactions were also carried out more with parents. Therefore, the role of parents in implementing the stages of the literacy movement during the Covid-19 pandemic has increased.

\section{Driving factors and inhibiting factors for the implementation of the school literacy movement during the Covid-19 pandemic}

The driving factor for implementing the school literacy movement during the Covid-19 pandemic included the availability of suitable facilities and cooperation with parents. The availability of facilities in implementing the school literacy movement is the existence of social media. It is also supported by the research results, which states that the teacher supporting factors in the online learning process are the availability of gadget (Putria et al., 
2020). A gadget is an essential tool in online activities, including the implementation of the school literacy movement.

Good collaboration with parents in implementing the school literacy movement is needed, especially during the Covid-19 pandemic. The school literacy movement is an effort or activity that is participatory by involving school members, including the parents/guardians of the parents (Rachmawati et al., 2017). Of course, it is done to optimize the achievement of the implementation of the school literacy movement.

Meanwhile, the inhibiting factors for the school literacy movement during the Covid19 pandemic were the lack of supporting facilities, unavailability of quotas, and the lack of teachers to control students' literacy development directly. The supporting facilities in question include the lack of reading books for students (Wiratsiwi, 2020). This lack of reading material was tricked by the school by lending books in turn to students.

Furthermore, the availability of quotas is also an obstacle in implementing the school literacy movement during the Covid-19 pandemic. The supporting factors for teachers in the online learning process are gadgets, quotas and a stable internet network (Putria et al., 2020). Without the availability of quota and a stable internet network, gadget cannot be used optimally. The teacher tricked the unavailability of an adequate quota by visiting students' homes on a scheduled basis.

Finally, the inhibiting factor for implementing the school literacy movement during the Covid-19 pandemic was the lack of teacher supervision indirectly controlling students' literacy development. Teachers and schools did this by doing good cooperation with parents. In addition, teachers' visits to students' homes are also a solution to factors inhibiting the implementation of the literacy movement.

\section{CONCLUSION}

The conclusions from the results of the research carried out were: 1) the pattern of literacy movements during the Covid-19 pandemic was adjusted to the level of developmental age of students and situations and conditions; 2) the literacy movement stage during the Covid-19 pandemic was carried out through three stages, namely habituation, development and learning, all of which were carried out online; 3) the driving factors for the implementation of the school literacy movement during the Covid-19 pandemic include the availability of good facilities and cooperation with parents; and 4) the inhibiting factors for the school literacy movement during the Covid-19 pandemic were the lack of supporting facilities, unavailability of quotas, and the lack of teachers to directly control the development of students' literacy.

Suggestions that can be written are based on the research that has been carried out, namely the need for digital-based reading materials that students can access. Students can access Digital-based reading materials at any time to support the implementation of the literacy movement during the Covid-19 pandemic. In addition, schools also need to socialize the stages of the literacy movement to parents/guardians of students to understand the school literacy movement better. Suggestions for further research should be that research subjects also involve students to find out the achievement of the school literacy movement program as a whole.

\section{REFERENCES}

1. Anggrasari, L.A. (2020). Application of E-Learning to Improve Digital Literacy Skills in the New Normal Era. Premiere Educandum: Jurnal Pendidikan Dasar dan Pembelajaran, 10(2), 248-256. http://ejournal.unipma.ac.id/index.php/PE/article/view/4254

2. Baterstock, A., Steinitz, J., Morris, J., \& Fenwick, C. (2019). What were the processes and outcomes of involving secondary school pupils transitioning from primary to secondary school in pre-arrival shared-reading? A case study. Education, 47(8), 933- 
956. https://doi.org/10.1080/03004279.2018.1541922

3. Coal, H.H., \& Ariani, D.N. (2018). Implementation of the School Literacy Movement Program in Public Elementary Schools of the Miai River Cluster, Banjarmasin. Journal of Elementary School Education, 4(1), 15-29. https://jurnal.untirta.ac.id/index.php/ jpsd / article / view / 2965

4. Buvaneswari, B., \& Padakannaya, P. (2017). Development of a home literacy environment questionnaire for Tamil-speaking kindergarten children. Language Testing in Asia, 7(1). https://doi.org/10.1186/s40468-017-0047-y

5. Dafit, F., \& Ramadan, Z.H. (2020). Implementation of the School Literacy Movement Program (GLS) in Elementary Schools. Basicedu's Journal, 4(4), 1429-1437. https://jbasic.org/index.php/basicedu/article/view/585

6. Faizah, D.U. (2016). Guide to the school literacy movement in elementary schools. In the Directorate of Primary School Development, Directorate General of Primary and Secondary Education, Ministry of Education and Culture.

7. Gellel, A.M. (2018). Towards a symbol literacy approach in the education of children. International Journal of Children's Spirituality, 23(2), 109-121. https://doi.org/10.1080/1364436X.2018.1448761

8. Handarini, O.I., \& Wulandari, S.S. (2020). Online Learning as a Study From Home (SFH) Effort During the Covid Pandemic 19. Journal of Office Administration Education (JPAP), 8(3), 496-503.

9. Herliandry, L.D., Nurhasanah, N., Suban, M.E., \& Kuswanto, H. (2020). Lessons During the Covid-19 Pandemic. JTP - Journal of Educational Technology. https://doi.org/10.21009/jtp.v22i1.15286

10. Higgs, J., Cherry, N., Macklin, R., \& Ajjawi, R. (2019). Qualitative Data Analysis. In Researching Practice.

11. Kurniawan, A.R., Chan, F., Abdurrohim, M., Wanimbo, O., Putri, N.H., Intan, F.M., \& Samosir, W.L.S. (2019). Teacher Problems in Implementing Literacy Program in Class IV Elementary Schools. Edustream: Journal of Elementary Education, 3 (2), 31-37. https://journal.unesa.ac.id/index.php/jpd/article/view/6390

12. Labudasari, E., \& Rochmah, E. (2019). The Influence of the School Literacy Movement on Students' Independent Character in SDN Kanggraksan Cirebon. Premiere Educandum: Jurnal Pendidikan Dasar dan Pembelajaran, 9(1), 57-63. http://ejournal.unipma.ac.id/index.php/PE/article/view/4254

13. Marmoah, S., Hartono, \& Sadiman. (2019). Implementation of School-Based Management Through a Culture of Literacy in Elementary School. DWIJA CENDEKIA: Journal of Pedagogical Research, 3(2), 238-247. https://doi.org/https://doi.org/10.20961/jdc.v3i2.35349

14. Pratiwi, I.M., \& Ariawan, V.A.N. (2017). Analysis of Students' Difficulties in Reading Beginning in First Grade Elementary School. Elementary School: A Study of Educational Theory and Practice, 26(1), 69-76. https://doi.org/10.17977/um009v26i12017p069

15. Putria, H., Maula, L.H., \& Uswatun, D.A. (2020). Analysis of the Online Learning Process (DARING) during the COVID-19 Pandemic in Elementary School Teachers. Basicedu's Journal.

16. Rachmawati, T.S., Rohanda, \& Winoto, Y. (2017). Appreciation of parents of students for the School Literacy Movement (GLS) program. Proceedings of the FKIP UNTIRTA National Education Seminar, 365-375.

17. Rigianti, HA (2020). Online Learning Constraints for Elementary School Teachers in Banjarnegara Regency. Elementary School, 7(2), 297-302. https://doi.org/https://doi.org/10.31316/esjurnal.v7i2.768

18. Suwandi, S. (2019). Literacy Education: Building a Learning Culture, Educator Professionalism, and Entrepreneurship Culture to Create National Spirit. In Bandung: Rosda Karya.

19. Tryanasari, D., Aprilia, S., \& Cahya, W.A. (2017). Learning Literacy at SDN Rejosari 1, Kawedanan District, Magetan Regency. Premiere Educandum: Jurnal Pendidikan Dasar 

dan
Pembelajaran,
$7(02)$,
173-179.
http://e-

journal.unipma.ac.id/index.php/PE/article/view/1641

20. Wiratsiwi, W. (2020). Implementation of the School Literacy Movement in Elementary Schools. EDUCATIC REFLECTION: Scientific Journal of Education, 10(2), 232--238. http://jurnal.umk.ac.id/index.php/RE\%0APENERAPAN

\section{PROFILE}

Atikah Mumpuni is a lecturer in the primary school teacher education study program, the faculty of teacher training and education, Muhadi Setiabudi University. She is also the editor of contextual scientific journals. In addition, She is active in research projects in the field of literacy in Elementary Schools.

Prasetyo Yuli Kurniawan is a lecturer in the study program of Indonesian language and literature education, faculty of teacher training and education, Muhadi Setiabudi University. He is the editor of a semantic scientific journal. In addition, he is active in research projects in the field of linguistics.

Rizki Umi Nurbaeti is a lecturer in the primary school teacher education study program, the faculty of teacher training and education, Muhadi Setiabudi University. She is active in research projects in the field of Natural Science literacy.

Annisa Nurul Fadillah is a student of the primary school teacher education study program, the faculty of teacher training and education, Muhadi Setiabudi University. She is often actively involved in various lecturer research projects.

Meri Yuliyanti, is a student of the primary school teacher education study program, the faculty of teacher training and education, Muhadi Setiabudi University. She is often actively involved in various lecturer research projects.

Nova Indriyani, is a student of the primary school teacher education study program, the faculty of teacher training and education, Muhadi Setiabudi University. She is often actively involved in various lecturer research projects. 